\title{
Covid-19 Pandemi Sürecinde İşletmelerin İnovasyon Kümesinin Pazarlama ve Yönetim Perspektifinden Değerlendirilmesi
}

\author{
V. Özlem AKGÜN* \\ M. Akif ÇİNï**
}

ÖZ

Günümüzde üretim ve hizmet ortamlarındaki değişim sürekli hale gelmiştir. Yaşanan hızlı değişimler karşısında işletme yöneticileri, zorlu pazar şartlarında hayatta kalabilmek için sürdürülebilir bir gelişim yolu aramak zorundadır ve bu yol, inovasyon faaliyetlerinin sürekli hale getirilmesinden geçmektedir. Pazarlama karmasının en önemli unsurlarından olan ürün, ancak değişen müșteri taleplerine ve ihtiyaçlarına uygun hale getirildiği takdirde daha fazla tercih edilir hale gelmektedir. Bununla birlikte yalnızca pazarlama açısından değil, yönetimsel açıdan da müşteri beklentileri ile uyumlu inovasyonlar gerçekleştirebilmek, işletmelere rekabet avantajı bağlamında oldukça önemli avantajlar sunmaktadır. Yönetim inovasyonu, ișlerin gerçekleștirilme biçimini, geleneksel yöntemlerden önemli ölçüde farklılaştırma yeteneğine sahip ve bu farklılaşma ile örgütün performansını artırmaya yardımcı olan bir kavrama karşılık gelmektedir.

Yapılan bu araştırmanın amac1; Covid-19 pandemi sürecinde işletmelerin inovasyon kümesinin, pazarlama ve yönetim perspektifinden ele alınmasıdır. Bu bağlamda araştırma; işletme, ürün, stratejik ve yönetim inovasyonlarından oluşan inovasyon kümesi bağlamında değerlendirilmiştir. Araştırmada nitel analiz yöntemlerinden "içerik analizi” kullanılmıştır. Bu kapsamda Konya ilinde faaliyet gösteren özel eğitim kurumlarının yöneticileri ile birebir görüşme yapılmıştır. Elde edilen veriler nitel araştırma yöntemlerinde sıklıkla kullanılan MAXQDA 18 programı aracılloğyla kodlanmıș ve sonrasında verilerin analizi gerçekleștirilmiștir. Yapılan bu araştırma sonucunda; Covid-19 pandemi dönemi sürecinde işletmelerin inovasyon kümesi kapsamında yönetim ve pazarlamaya yönelik mevcut ve gelecek projeksiyonları açısından çeşitli inovasyonlar gerçekleştirdikleri tespit edilmiştir.

Anahtar Kelimeler: İnovasyon Kümesi, Pazarlama İnovasyonu, Yönetim İnovasyonu, Covid-19 Pandemisi.

\section{Evaluation of the Innovation Cluster of Businesses From the Marketing and Management Perspective in the Covid-19 Pandemic Process}

\begin{abstract}
Today, change has become continuous in production and service environments. In the face of rapid changes, business managers have to seek a sustainable development path in order to survive in challenging market conditions, and this road passes through the continuation of innovation activities. The product, which is one of the most important elements of the marketing mix, becomes more preferred only if it is adapted to changing customer demands and needs. On the other hand, being able to realize innovations that are compatible with customer expectations not only in terms of marketing but also in terms of management is considered as a very important obligation in terms of competitive advantage. Management innovation is a concept that has the ability to significantly differentiate the way practices are done from those of the traditional methods.

The purpose of this research is to consider the innovation cluster of businesses from a marketing and management perspective during the Covid-19 pandemic process. In this context, the research has been evaluated in the context of an innovation cluster consisting of business, product, strategic and management innovations. Content analysis, one of the qualitative analysis methods, was used in the study. In this context, one-on-one meetings were held with the managers of private education institutions operating in Konya. The data obtained were coded using the MAXQDA 18 program, which is frequently used in qualitative research methods, and then the data were analyzed. As a result of this research, it was determined that during the Covid-19 pandemic period, enterprises carried out various innovations in terms of current and future projections for management and marketing within the scope of the innovation cluster
\end{abstract}

Keywords: Innovation Cluster, Marketing Innovation, Management Innovation, Covid-19 Pandemic.

1. Giriş

"İnovasyon, yeni bir şeyler üretmekten çok, müşteriler için yeni ve önemli bir şeyi mümkün kilmakla ilgilidir." (Clayton Christensen, İnovasyonda Ustalaşmak)

\footnotetext{
* Dr. Öğr. Üyesi, Selçuk Üniversitesi, ozlemakgun@selcuk.edu.tr

** Dr. Öğr. Üyesi, Selçuk Üniversitesi, mehmetakifcini@selcuk.edu.tr

Makalenin Gönderim Tarihi: 30.12.2020; Makalenin Kabul Tarihi: 08.01.2021
} 
Yaratıcıllk yeni ve yararlı fikirlere karşıllk gelen bir kavram iken, inovasyon bir organizasyon içinde yaratıcı fikirlerin başarılı bir biçimde uygulanmasıdır. Yaratıclık bireysel düzeyde, inovasyon ise örgütsel düzeyde gerçekleşmektedir (Gümüşlüoğlu \& İlsev, 2009, s. 461).

Pazarlamanın özünde, doğru mal ve hizmetlerin doğru kitleye, doğru yerde, doğru zamanda ve doğru fiyatta sunulması yer almaktadır. Bugünün müşterisi ise tüm bunları talep etmenin ötesinde sürekli olarak kendisine inovatif ürünlerin sunumu beklentisinde olan talepkâr bir profile sahiptir. Bilginin özü kabul edilmiş değerli enformasyonların, entegre verilerin, gerçeklerin, deneyimlerin, sezgilerin ve hatta hipotezlerin karşılaştırlması olarak düşünülmektedir (Brilman, 2002, s. 295). Yönetim ise M.P. Follett’a göre, "başkaları vasıtasıyla iş görme sanatıdır" (Devane \& Wilson, 2009, s.32) ve bu süreçte modern iş organizasyonlarında gördügümüz uygulamaların, süreçlerin ve yapıların çoğu, son 150 yılda yenilikçi anlayışa sahip yönetim çalışanlarının yaratıcı çabaları ile geliştirilmiştir (Birkinshaw \& Mol, 2006, s. 81). Yenilikler, insan icadının ürünleridir ve bu nedenle insanlar tarafından sahip olunan bilginin işlenmesi sonucu ortaya çıkmışır. Yenilikçiliğin kapsamı ve ölçeği bu bağlamda insan bilgisi alanında gerçekleştirilen değişiklikleri de göstermektedir (Markiewicz, 2010, s. 14). Bilgi, inovasyon yaratma sürecinin temel bileşen unsurunu oluşturmaktadır fakat bilgiye sahip olmak, bir örgütte inovasyon başlangıcının garantisi olarak düşünülmemelidir. Özellikle hizmet işletmelerinde bilgi, genellikle teknolojiden daha önemli bir avantaj olarak değerlendirilmektedir (Wojtkiewicz, 2017, s. 52). İnovasyon çalışmalarının önemli yer edindiği alanlardan birisi eğitimdir. Eğitim pazarlaması, piyasada yer alan bir eğitim kurumunun yönetiminde önemli faaliyet alanlarından birisi olarak değerlendirilmektedir (Biloshkurska vd., 2017, s. 27). Belirlenen standartların üzerinde eğitim sunmak için araştırmalar gerçekleştiren ve kaliteli eğitim sunma konsepti ile hareket eden kurumlar, sektörde rekabet açısından önemli üstünlükler elde etmektedir. Eğitim hizmetleri; bireyin, toplumun ve devletin ihtiyaçlarını karşılamak için kullanılan bilgi, enformasyon, beceri ve uygulama sistemine karşlık gelen bir kavramdır. Bir eğitim hizmeti veya eğitim faaliyetinin ürünü, bireylerin ve tüm toplumun eğitim ihtiyaçlarını karşılamak için eğitim çalışanlarının pedagojik, eğitimsel, bilimsel, örgütsel ve yönetsel faaliyetlerinin sonucudur (Braslavska vd., 2019, s. 404).

\section{Literatür Çalışması}

\subsection{Pazarlama ve Yönetim Açısından İnovasyon}

İnovasyon, hızlı hareket eden bir küresel ekonomide, işletmeler için hem gerekli bir araç hem de arzu edilen bir amaçtır. Bu durum; müşterilere yeni mal ve hizmetleri rakiplerinkinden daha verimli, etkili ve hızlı bir şekilde sunan bir süreci yönetmek veya süreç iyileştirmek yoluyla mevcut mal ve hizmetlerin sunumunu geliştirmekle ilgilidir (Kalivas vd., 2013, s. 14). İnovasyon kavramıyla ilgili literatürde pek çok çalşsma olmasına rağmen bu çalışmaların çoğunda, ürün ya da süreç inovasyonlarına atıfta bulunulmakta, pazarlama ve yönetim gibi alanlardaki teknolojik olmayan yenilikler büyük ölçüde göz ardı edilmektedir.

Bir işletmenin faaliyet gösterdiği sektörde başarılı olabilmesi ve tüketicilerin ve paydaşların istek ve gereksinimlerini karşılayabilmesi için sunmuş olduğu mal ve hizmetlerle ilgili Ar-Ge faaliyetlerine yatırım yapması önemli bir gereklilik olarak düşünülmektedir. Bu gerekliliğin yerine getirilmesi ise, ancak yapılacak pazarlama inovasyonları sayesinde mümkün hale gelmektedir. Bugün, yeni fikirler değer zincirinin herhangi bir bölümünü olumlu yönde dönüştürebilmektedir. Mal ve hizmet yeniliği, yalnızca bir başlangiçtır. $\mathrm{Bu}$ sebeple, işletmelerin yeni pazarlama yöntemlerine yatırım yaptığı her türlü çaba ve kaynak pazarlama inovasyonu olarak kabul edilmektedir ve rekabet gücünü artırmak için en az teknolojik yenilik kadar önemlidir (Birkinshaw vd., 2011; Medrano, vd., 2020, s. 2). İnovasyon ve pazarlama genellikle bir madalyonun iki yüzü olarak görülmektedir. Yarım asır önce Peter Drucker'n "İşletmenin amacı müşteri kazanmak olduğu için işletmelerin de iki -ve yalnızca iki- temel işlevi bulunmaktadır: Bu işlevler; pazarlama ve inovasyondur. Pazarlama ve yenilik sonuç üretir; geri kalan her şey maliyettir" sözü inovasyonun önemini vurgulamaktadır (Drucker, 1954, s. 39; Purchase \& Volery, 2020, s, 763). Pazarlama inovasyonu, mevcut pazarlama stratejilerinde ve yöntemlerinde pazarlama karması unsuları çerçevesinde yapilan yenilikler olarak ifade edilebilmektedir (Nadda \& Arnott, 2019, s. 403). Pazarlama inovasyonuna yönelik literatürde yer almış bazı tanımlamalar Tablo 1'de özetlenmiştir. 
Tablo 1. Pazarlama İnovasyonu Tanımları

\begin{tabular}{|c|c|}
\hline Tanımlar & Referanslar \\
\hline $\begin{array}{c}\text { Yeni hizmetlerin geliştirilmesi, yeni fiyat belirleme stratejisi, } \\
\text { yeni reklam promosyonları, yeni dağıtım kanalları ve } \\
\text { pazarlama bilgi sistemleri }\end{array}$ & Gupta vd. (2016, s. 5673) \\
\hline $\begin{array}{l}\text { Yeni fiyatlandırma yöntemleri, yeni dağıtım yöntemleri, yeni } \\
\text { satış yaklaşımları, kiralama düzenlemeleri ve yeni bir pazara } \\
\text { girme }\end{array}$ & Weerawardena (2003, s. 34) \\
\hline $\begin{array}{l}\text { İşletmenin, müşterilerin mevcut ve gelecekteki ihtiyaçlarını } \\
\text { karşıllamak için yeni çözüm önerileri geliştirebilme yeteneği }\end{array}$ & Ngo \& O’Cass (2012, s. 865); O’Dwyer vd. (2009) \\
\hline $\begin{array}{c}\text { Pazarlama karmasındaki değişiklikler; ürün tasarımı, dağıtım } \\
\text { kanalları, tutundurma ve fiyatlama yöntemlerinde } \\
\text { iyileştirmeler }\end{array}$ & $\begin{array}{c}\text { Kafetzopoulos \& Psomas (2016); Naidoo (2010, s. 56); Shergill ve } \\
\text { Nargundkar (2005); Tsourvakas vd. (2016) }\end{array}$ \\
\hline $\begin{array}{l}\text { Ürün tasarımı veya ambalajı, ürün yerleştirme, ürün tanıtımı } \\
\text { veya fiyatlandırmada önemli değişiklikler içeren yeni bir } \\
\text { pazarlama yönteminin uygulanması (Oslo Kılavuzu, 2005) }\end{array}$ & $\begin{array}{l}\text { Bartoloni \& Baussola (2016); Bortoluzzi vd. (2018); Camisón ve } \\
\text { Villar-López (2011); Cruz-Ros vd. (2017); Geldes vd. (2017); } \\
\text { OECD (2005, s. 45); Medrano \& Olarte-Pascual (2016); Ramirez } \\
\text { vd. (2018); Wong (2013) }\end{array}$ \\
\hline Satışları artırmak için yeni teknikler ve araçlar & Fuentes-Blasco vd. (2017) \\
\hline $\begin{array}{c}\text { Yeni pazarlama yöntemleri geliştirilmesi ya da önceden } \\
\text { varolan pazarlama yöntemleri arasında ciddi değişiklikler } \\
\text { geliştirilmesi ve uygulanması }\end{array}$ & Biçimveren (2017, s. 30) \\
\hline $\begin{array}{c}\text { Ürünü müşterilerin ihtiyaçlarına göre uyarlama ve müşteri } \\
\text { yönetimi alanında yenilik yapma }\end{array}$ & Sánchez-Gutiérrez vd. (2019, s. 619) \\
\hline $\begin{array}{c}\text { İşletmelerin pazara yaklaşımlarında iletişim kanallarını etkin } \\
\text { bir şekilde kullanma ve potansiyel müşterileri kazanma veya } \\
\text { mevcut müşterileri elde tutma için mal ve hizmet sunma } \\
\text { becerisi }\end{array}$ & Lee vd. (2019, s. 509) \\
\hline
\end{tabular}

Pazarlama alanında inovasyon yapılmasının en önemli nedenleri arasında; sınırların ortadan kalkması, değişen müşteri beklentileri ve değişim hızı gibi önemli faktörler yer almaktadır (Doyle \& Bridgewater, 1998, s. 1-3). Pazarlama inovasyonu genellikle ürün inovasyonu, ürün konumlandırma, tutundurma faaliyetleri ve fiyatlandırma üzerine yoğunlaşmaktadır (Biçimveren, 2017, s. 32). Bununla birlikte Wang’a (2015) göre, pazarlama inovasyonu ile ilgili literatür özellikle üç ana konu altında şekillenmektedir. Bu konular: (a) pazarlama inovasyonu veya inovasyon ve pazar performansı ilişki yoluyla elde edilebilecek rekabet avantajlan (b) pazarlama inovasyonu ile diğer inovasyon türleri arasındaki ilişkilerin yanı sıra teknolojik ve teknolojik olmayan inovasyon arasindaki benzerlikler ve farkliliklar (c) pazarlama inovasyonlarını benimseyen işletmelerin özelliklerini tespit etme, şeklinde ifade edilebilmektedir.

Yönetim açısından inovasyona bakış değerlendirildiğinde; özellikle son yarım yüzyılda bilimde, teknolojik alanda, yaşam biçimlerinde meydana gelen radikal değişiklerle kıyaslandığında, yönetim uygulamalarının çok daha yavaş bir dönüşümden geçtiği ifade edilebilmektedir (Soylu \& Göl, 2010, s. 119). Yönetimsel bakış açısıyla inovasyon, organizasyonun yönetilme şeklini iyileştirmeye dayanan bir yaklaşıma sahiptir Bugünün modern yöneticilerinden beklenen yaklaşım; inovasyonun örgütsel yaşam üzerindeki hayati etkisinin tüm pozisyonlarda vurgulanması şeklindedir. Sistemlerdeki değişimlerin, yeni süreçlerin ve iyileștirmelerin tüm detayları ile ele alınması sayesinde rekabetçi baskıların üstesinden gelmek mümkündür (Kalivas vd., 2013, s. 14). İnovasyon konusunda çeşitli çalışmaları bulunan Peter Drucker’a göre, inovasyon sadece bir sonuç olarak değil, bir süreç olarak da değerlendirilmesi gereken bir kavramdır. Başarılı bir inovasyon yönetiminin sürdürülebilirliğini sağlamak için inovasyonla ilgili sonuçlara bakmanın yetersiz olduğunu kabul eden işletmeler, inovasyonun sürdürülebilirliği açısından süreç boyunca derinlemesine çalışmak için çaba göstermek durumundadır (Aygen, 2006, s. 57). Bu bağlamda inovasyon yönetiminin, geleceğin yönetimi olduğunu söylemek yanlış olmayacaktır. Geniş anlamda inovasyon, işletmeleri rekabet etmek için değişim yapmaya iten teşvik edici bir güçtür. Birçok sektörde işletmeler ayakta kalabilmek için kendilerini, yeni ürünler geliştirmeye, yeni örgütsel modelleri uygulamaya, yeni pazarları keşfetmeye mecbur hissetmektedir. Örneğin yeni bir öğrenme metodu geliştiren bir kişi, yenilikçi okulların hangileri olduğunu bilmek isteyecektir (Gümüş \& Gümüş, 2015, s. 263). Yapılan açıklamalardan 
da anlaş1labileceği üzere inovasyon faaliyetlerini sürdürmenin hem pazarlama açısından hem de yönetimsel açıdan, bir işletmeye özellikle rekabet avantajı sağlama bakımından önemli firsatlar sunduğu rahatıkla ifade edilebilmektedir.

Yönetim inovasyonuna yönelik literatürde yer almış bazı tanımlar Tablo 2'de gösterilmektedir.

Tablo 2. Yönetim İnovasyonu Tanımları

\begin{tabular}{|c|c|}
\hline Tanımlar & Referanslar \\
\hline $\begin{array}{c}\text { Illk ortaya çıktığı andan itibaren karar verme süreçlerinde bilginin niceliği veya niteliği, yerini ile doğasını } \\
\text { etkileyen ve yönetimin gidişatından önemli sapmalara yol açan ürün, program veya süreçtir. }\end{array}$ & Kimberly (1981, s. 86) \\
\hline $\begin{array}{c}\text { Geleneksel yönetim ilkelerinden, süreçlerinden ve uygulamalarından veya yönetim çalışmasının } \\
\text { gerçekleştirilme şeklini önemli ölçüde değiştiren geleneksel organizasyonel biçimlerden belirgin bir } \\
\text { sapmadır'. }\end{array}$ & Hamel (2006, s. 4) \\
\hline $\begin{array}{c}\text { Modern bir yönetim uygulamasının, sürecinin, yapısının veya tekniğinin oluşturulması ile uygulanmasıdır } \\
\text { ve örgütsel hedefleri ilerletmeyi amaçlamaktadır. }\end{array}$ & $\begin{array}{c}\text { Birkinshaw vd. (2008, } \\
\text { s. 829) }\end{array}$ \\
\hline Firma için yeni olan ve firma performansını artırmayı amaçlayan yönetim uygulamalarıdır. & $\begin{array}{c}\text { Mol \& Birkinshaw } \\
(2009, \text { s. 1269) }\end{array}$ \\
\hline
\end{tabular}

Kaynak: Volberda, H.W., Van Den Bosch, F.A.J.\& Heij, C.V. (2013). Management innovation: Management as fertile ground for innovation. European Management Review, 10, 1-15, s. 3’ten uyarlanmıştır.

\subsection{Pazarlama ve Yönetim Açısından İnovasyon Kümesinin Değerlendirilmesi}

İnovasyon konusunda literatüre önemli katkılar sunan Hamel ve Breen'e göre (2007) inovasyon; yönetim inovasyonu, stratejik inovasyon, ürün inovasyonu ve işletme inovasyonu olmak üzere farklı kategorilerde ve seviyelerde gerçekleşebilmektedir. Sayllan inovasyon türlerinden her biri, işletme başarısına kendi katkısını sunmaktadır. Daha yüksek seviyelerin, daha yüksek değer yaratma ve rekabetçi savunmayı ifade ettiği bir hiyerarşik yapı içinde, inovasyon türleri sıralaması açısından değerlendirme yapıldığında, Şekil 1'de yer alan inovasyon kümesi piramiti ortaya çıkmaktadır.

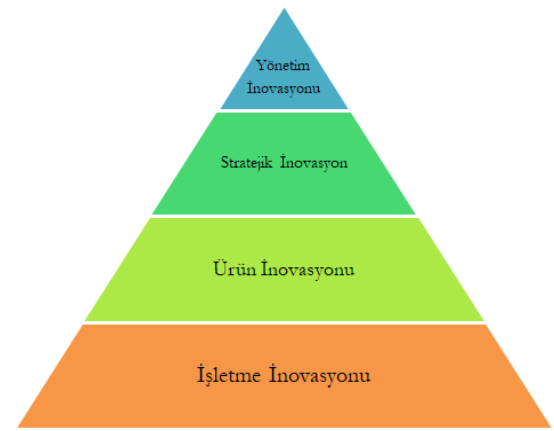

Şekil 1. İnovasyon Kümesi

Kaynak: Hamel, G. \& Bren, B. (2007). The Future of Management, Harvard Business Scholl Press. s. 32.

\subsubsection{Yönetim İnovasyonu}

Örgütsel yapılarda ve rollerde değer yaratıcı değişimleri kapsayan yönetim inovasyonu, yönetim fonksiyonunun yapılış şeklini önemli ölçüde değiştiren ya da alışılmış örgütsel biçimlerde ciddi değişiklik yaparak örgütsel hedefleri ilerleten her şey olarak ifade edilebilmektedir (Hamel \& Bren, 2007, s. 15-18). Yönetim inovasyonu, mevcut normlardan önemli ölçüde farklılaşan yeni yönetim uygulamalarının, süreçlerinin ve yapılarının uygulanmasına karşıllı gelmektedir. Yönetim inovasyonu sayesinde bugün modern iş organizasyonlarında pek çok işlevin ve faaliyetin yapılma şekli önemli ölçüde değişim göstermektedir (Birkinshaw \& Mol, 2006, s. 81). Yönetim inovasyonu, bir işletmenin kullanabileceği yenilik türleri arasında en yüksek ve en değerli olanını temsil etmektedir (Grant, 2008, s. 471). Yönetim inovasyonu, örgütsel yapı üzerinde ve rollerde değer yaratan birtakım değişimleri de içermektedir. İşletmenin çevresini oluşturan paydaşlar ile kendisi arasındaki ilişkilerin daha güçlü bir hale getirilmesi, devamlılığın sağlanması bağlamında önemli bir katalizör vazifesi gören bir yaklaşım biçimi olarak da ele alınabilmektedir. Yönetim inovasyonu bünyesinde bir takım temel aykırılıklar taşıdığından, yinelenmesi zor avantajlar ortaya koymak için benzersiz bir kapasiteye sahiptir. Özellikle üst kademe yöneticilerin 
geleneksel konumlarını sorgulamaları ve köklü yönetim anlayışlarının terk edilmesini mecbur kılması taklit edilme ihtimalini oldukça azaltmaktadır (Lynch 2007; Soylu \& Göl, 2010, s. 118-121).

\subsubsection{Stratejik İnovasyon}

Pek çok araştırmacı tarafindan strateji ve yeniliğin bir kombinasyonu olarak kullanılan stratejik inovasyon; rekabetçi piyasada pazarda kalıcı olmak için avantajlar elde etmeye yönelik bir yaklaşım olarak ele alınmaktadır. Stratejik inovasyon, sektör dinamiklerini anlama ve değiştirme becerisidir. Nihayetinde bu durum, paydaşlar için yeni varlık sağlama yollarını geliştirme, hizmeti yeniden tasarlayarak ve pazarı yeniden tanımlayarak müşteriler için değer yaratma gibi birtakım avantajları da beraberinde getirmektedir (Hamel, 1996, 1998). Bir stratejik inovasyon; değer zinciri tasarımı, müşteri değerinin kavramsallaştırılması ve potansiyel müşterilerin belirlenmesi alanlarından en az birinde geleneksel uygulamalardan farklılaşma sağlamaktadır (Govindarajan \& Trimble, 2004, s. 21). Stratejik olarak yenilikçi organizayonlar; yeni kaynakları kullanma, potansiyel müşterileri kazanma, karlı olanların yanında, daha az karlı olan müşterilere de odaklanma, pazarı farklılıklardan ziyade benzerliklere göre segmentlere ayırma, stratejik fiyatlama yöntemleri kullanma gibi politikalar benimseyen yapilara sahiptir. Bu nedenle stratejik inovasyon yaklaşımını benimseyenler yalnızca var olan müşterileri elde tutmanın ötesinde, yeni fırsatlar yaratma potansiyeline sahip pazarlar aramaya da odaklanmaktadır (Schlegelmich vd., 2010, s. 121). Bu bağlamda stratejik inovasyonun; yeni pazarların keşfedilmesine, müşteri ve organizasyon için değer artış1 sağlanmasına ve yeni iş modellerinin geliştirilmesine önemli katkılar sunduğu ifade edilebilmektedir (Sniukas, 2010). Yeni iş modelleri oluşturulmasının, var olan pazarda boşluklar yaratılmasının ve bununla birlikte müşteri değerinin artırılmasının yeniden kavramsallaştırılmasının amaçlandığı stratejik inovasyonda, üç temel unsur yer almaktadır. Bu unsurlar: (a) üst kademe yöneticilerin başarılı olmak amacıyla geleceği ve bugünü içeren stratejik düşünebilme becerileri (b) inovasyon için yaratıcı fikir geliştirme ve analitik düşünebilme şeklinde farklı organizasyonel niteliklere ihtiyaç duyulması ve (c) bugünün rekabet anlayışının rekabet yarışının kurallarıyla farklılaşan iş modellerine oranla, daha az ürün ya da teknoloji temelli olması olarak ifade edilebilmektedir (Gebauer, 2012, s. 57; Drejer, 2006, s. 144; Hancı̆̆olu \& Yeşilaydın, 2016 , s. 109).

Geleneksel yaklaşım ve stratejik inovasyon yaklaşımı arasındaki farklar Tablo 3’te gösterilmiştir.

Tablo 3. Geleneksel Yaklaşım ve Stratejik İnovasyon Yaklaşımı Karşılaştırması

\begin{tabular}{|c|c|}
\hline Geleneksel Yaklaşım & Stratejik İnovasyon Yaklaşımı \\
\hline $\begin{array}{l}\text { "Bugünden, geleceğe düşünme yönelimi”'- başlangıç } \\
\text { noktası olarak bugünü alır. }\end{array}$ & $\begin{array}{c}\text { "Sonu akılda tutan düşünme yönelimi"'-uzun vadeli } \\
\text { firsatları akılda tutarak sonla başlar ve ardından } \\
\text { şimdiki zamana köprüler kurar. }\end{array}$ \\
\hline Kural koyucu savunmacı/takipçi duruş & Kural bozucu (devrimci) duruş \\
\hline Sabit (yerleşmiş) iş tanımlamaları/ürün kategorileri & Yeni rekabetçi alanlar \\
\hline Artan yeniliğe odaklanma & Çığır açan, parçalayıcı yenilikler \\
\hline Geleneksel, doğrusal iş planlama modelleri & Süreç disiplinini yaratıc ilhamla birleștiren modeller \\
\hline Açık ve geleneksel kaynaklardan girdi arama & Alışılmadık kaynaklardan girdi arama \\
\hline Belirlenmiş tüketici ihtiyaçlarına odaklanma & Belirlenmemiş tüketici ihtiyaçlarına odaklanma \\
\hline $\begin{array}{c}\text { Teknoloji odaklı } \\
\text { (Tüketici memnuniyeti arama) }\end{array}$ & $\begin{array}{l}\text { Tüketiciden ilham alma/esinlenme } \\
\text { (Tüketici hazzı arama) }\end{array}$ \\
\hline Herkese uyan organizayon modeli & Yeni/riskli organizasyon modelleri \\
\hline
\end{tabular}

Kaynak: Palmer, D. \& Kaplan, S. (2007). A framework for strategic innovation-blending strategy and creative exploration to discover future business Opportunities, Innovation Point LLC, (Online) http://www.fastbridge.net/wpcontent/uploads/resources/A\%20framework $\% 20$ for $\% 20$ strategic\%20innovation.pdf., 21.24.2017, 1-22. s. 6

Temelde stratejik inovasyon, stratejik deneyler gerektirmektedir. Bu stratejik deneylerin sahip olduğu temel özellikler şu şekilde sıralanabilmektedir (Govindarajan \& Trimble, 2005, 48-49):

- Stratejik deneyler, öğrenmeyi gerektirmektedir.

- Stratejik deneyler yalnızca teknolojik gelişme ya da coğrafi genişleme anlamına gelmemektedir.

- Stratejik deneyler yetersiz tanımlanmıs sektörleri hedef almaktadır

- Stratejik deneyler, ödünç almayı gerektirmektedir.

- Diğer rakiplerden önce stratejik deneyler başlatılmaktadır. 
- Stratejik deneyler, yeni yetenekler ve bilgi gerektirmektedir.

- Stratejik deneyler geliri arturma potansiyeline sahiptir.

- Stratejik deneyler, yöneticiler tarafindan yönetilmektedir.

- Stratejik deneyler hakkında geri bildirim almak zor olabilmektedir.

- Stratejik deneylerin tekrarlanması pahalıdır.

Stratejik inovasyon, rakipleri savunmaya geçiren, önemli kazançlar getirme potansiyeline sahip yeni iş modellerini ve süreçleri içermektedir. Öne çıkan örnekler arasında Avrupa'nın önde gelen düşük maliyetli havayolu Ryanair, Apple'ın i-Tunes müzik mağazası, Zara'nın şık ama nispeten ucuz modası yer almaktadır. Bununla birlikte stratejik inovasyona dayalı bir iş modeli oldukça kazançlı bir model olarak düşünülse de bu ayırt edici modelin çözülmesi ve etkisiz hale getirilmesi çok da zor değildir. Örneğin; Wallmart'n indirimli perakendecilikte sözde yenilmez liderliği, Costco ve Target gibi diğer perakendecilerin sektörde gelişmesini engelleyememiştir (Hamel \& Breen, 2007, s. 33).

\subsection{3. Ürün İnovasyonu}

Pazarlama inovasyonu, geleneksel kalıpların dışına çıkmaya dayalı pek çok ürün inovasyonunu da kapsamaktadır. Ancak bu durum, mevcut ya da potansiyel müşterileri rahatsız edecek düzeyde değil, aksine onların memnuniyetini artırmaya hizmet edecek biçimde gerçekleştirilmektedir. İşletmelerin faaliyetlerini sürdürmeleri ve gelişimlerini devam ettirmeleri, yeni ürün süreçlerini; üretim fikrinin oluşmasından ürünün lansmanına ve satış sonrası hizmetlere kadar etkin bir şekilde yönetebilmeleri ile mümkündür (Cooper \& Kleinschmidt, 1987, s. 215). Bir başka deyişle ürün yeniliği, bir işletmenin gelişiminde hayati rol oynamaktadır. Ürün inovasyonundaki başarı bileşenlerinin doğru olarak anlaşılması ve yorumlanması bu bağlamda oldukça önemli kabul edilmektedir. Ürün inovasyonlarının işletme performansı üzerindeki etkilerinin incelendiği pek çok araştırmada, bu iki kavramın birbiri ile bütünleştiğine yönelik düşüncenin, hakim görüş olarak ortaya çıktı̆̆ ifade edilebilmektedir. Aksoy (2017), Kuncoro \& Suriani (2018), Muigai \& Gitau (2018) tarafindan yapılan çalşsmalarda, ürün inovasyonunun; pazar performansını, finansal performansı ve sürdürülebilir rekabet avantajını olumlu yönde etkilediği sonucu elde edilmiştir (Zhang, Sun, Liu \& Chang, 2020, s. 3). Benzer şekilde Hultink \& Robben (1995), Milson (2013) ve Warren \& Sorescu (2017) tarafindan gerçekleştirilen çalışmalarda da ürün inovasyonunun, yeni ürün performansını olumlu yönde etkilediği sonucuna varılmıştır. Ürün inovasyonu, ürünün başarısı için kritik öneme sahiptir ve bu durum da sürdürülebilir iş başarısıyla yakından ilgili olup işletmeler için büyüme ve yeni alanlarda genişleme açısından önemli firsatlar sunmaktadır (Cooper, 2000, s. 38). Ürün inovasyonu, bir ürünün pazarlanmasında yer alan teknik tasarım, Ar-Ge, üretim, yönetim ve ticari faaliyetleri içeren bir süreç olarak tanımlanmaktadır (Alegre \& Chiva, 2008, s. 118). Ürün inovasyonunda işletmeler için oldukça önemli üç temel unsur söz konusudur. Bu unsurlar (Cooper \& Kleinschmidt, 1995; 1996): (a) yeni ürün projelerini hızlı ve başarılı bir şekilde piyasaya sürmek için gerekli yol haritası (b) ürün inovasyonuna ayrılmış doğru ve yeterli kaynak (3) iş için yeni bir ürün ve teknoloji stratejisinden oluşmaktadır. Yeni ürünlerin yaratılması; tüketiciler ve işletmeler için değer yaratma bağlamında kritik bir rol üstlendiğinden, inovasyonun tüm karmaşık yapısı içindeki esas olan özünü oluşturmaktadır (Negulescu, 2020, s. 68). Hiç şüphe yoktur ki; ikonik bir ürün bir işletmeyi karanlık ve bilinmez bir ortamdan kısa sürede zirveye taşıyabilmektedir. Örneğin; Dyson markasının torbasız süpürgesi bu durumun en çarpıcı örneklerindendir. Bununla birlikte uygulanabilir bir patent korumasının yokluğunda, çoğu ürünün avantajı hızla ortadan kaybolmaktadır. Buna ek olarak, teknolojik ilerlemenin sürekli artan hızı, genellikle yeni başlayanlara dünün öncülerini atlatma firsatı vermekte ve çığır açan ürünler nadiren bir markaya uzun süreli sektör liderliği sağlamaktadır. Örneğin; Nokia'nın süper ince cep telefonu tasarımının Samsung tarafından geliştirilmesi yalnızca birkaç yll içinde gerçekleşmiştir (Hamel \& Breen, 2007, s. 33).

Pazarlama, dağıtım ve ürün bağlamında inovasyon stratejisi dört kategoride incelenebilmektedir (Kalivas vd., 2013, s. 22):

(a) Teknolojik (Yeni olmayan bir pazardaki yeni ve özgün ürünler): Bilinen müşteri ihtiyaçları yeni mal ve hizmetlerle karşlanmaktadır. Örneğin; telefon sistemlerinde bakır tellerin yerini alan film optiklerinin kullanılması. Sonuç olarak, bu durum hizmetlerde ve çağr1 netliğinde önemli bir gelişme olarak kabul edilmiştir. Bu durumda ana pazarlama hamlesi, daha yüksek performans 
seviyelerini ifade etmek şeklinde ortaya çıkmaktadır ve inovasyon, ürün geliştirici tarafindan yönlendirilmektedir.

(b) Farklılaştırllmış (Yeni olmayan bir pazardaki mevcut ürünler): Bu durumda ürün ve pazar nispeten iyi bilinmektedir ve ürünler arasında ayrım yapmanın tek yolu; fiyatları, ambalaj1 ya da ürün desteğini kullanmaktır.

(c) Mimari (Yeni bir pazardaki mevcut ürünler): İnovasyon fikrini benimsemiş pazarlama yöneticisi, varolan bir mal ya da hizmeti yeni bir pazara sunmaya çalışmaktadır.

(d) Karmaşık (Yeni pazarlara sunulan yeni ürünler): Bu ürünlerin pazarlanması yüksek derecede hayal gücü ve sezgi gerektirmektedir.

Üstün ürün kalitesi ve tasarımını içeren ayırt edici özelliklerle geliştirilen yeni ürünler ve genişletilmiş hizmetler, tüketicilere benzersiz değer katma potansiyeli taşırken, işletmeler de daha yüksek performans elde edebilmektedir. Aynı zamanda bir işletmenin yeni ürün geliştirme ve pazarlama faaliyetlerini daha düşük bir maliyetle gerçekleştirebilmesi, yeni ürünün sağlamış olduğu önemli bir avantaj olarak değerlendirilmektedir. Bu bağlamda işletmelerin yeni ürün geliştirme başarısının, bir işletmenin pazar yönelimi ile yakından ilgili olduğu da ifade edilebilmektedir (Kim \& Atuahene-Gima, 2010, s. 522).

\subsection{4. İşletme (Operasyonel) İnovasyon}

Bir işletmenin, faaliyetlerini sürdürmesinin ve rekabet avantajını korumasının en ekili yollarından birisi dinamik pazar ortamında gerçekleştireceği inovasyon çalışmalarının süreklilik arz etmesidir. İşletme inovasyonu, esas olarak çalışanların iş verimliliklerini artırmak ya da belirlenen hedeflere ulaşabilmek ve ardından örgütsel performansı artırmaktır (Wang, 2020, s. 39). Bir örgüt tarafindan benimsenen bir fikir, yeni bir ürün, yeni bir yöntem, yeni bir hizmet, yeni bir süreç, yeni bir teknoloji veya yeni bir strateji kavramına karşılık gelen işletme inovasyonu; aynı zamanda bir örgüte yeni bir şeyin tanıtılması anlamını da taşımaktadır. İşletme inovasyonu (örgütsel inovasyon) çalışmaları; üç farklı araştırma sorusuna yönlendiren üç farklı biçimde sınıflandırılabilmektedir (Demircioğlu, 2016, s. 2; Lam, 2006, s. 116-136):

(a) Örgütsel yap1 ve tasarım teorileri: Örgütsel analiz seviyesinde örgütlerin yapısal unsurlarının, örgütlerin inovasyon yapma eğilimini nasıl etkilediğine odaklanmaktadır.

(b) Örgütsel kavrama ve öğrenme kuramlarr: Analiz düzeyinin mikro odak noktası olan örgütsel kavrama ve öğrenme kuramları, örgütsel inovasyonun bilişsel temellerine ve bilgi yaratma potansiyeline odaklanmaktadır (Örneğin; problem çözme inovasyonları).

(c) Örgütsel değissim ve uyum kuralları: Analiz düzeyinin örgütsel ve dış çevre olduğu örgütsel değişim ve benimseme/uyum teorileri, örgütlerin çevresel değişimlere ve teknolojik gelişmelere adapte olma/olamama durumlarına odaklanmaktadir.

Bugünün hiper rekabet dünyasında operasyonel mükemmellik esastır, fakat Toyota benzeri yönetim yeniliği veya İkea tarzı iş modeli atılımının yokluğunda işletme inovasyonu nadiren belirleyici ve uzun vadeli bir avantaj sağlamaktadır (Hamel \& Breen, 2007, s. 32). İşletme inovasyonu, çoğunlukla haberleşme alt yapısının kalitesine dayanmakla birlikte donanım ve yazılımdaki avantajların hızla yaygınlaşması neticesinde bu alandaki avantajın yitirilmesi oldukça kolay bir hale gelebilmektedir (Soylu \& Göl, 2010, s. 120).

\section{Araştırmanın Metodolojisi}

\subsection{Araştırmanın Amacı ve Veri Toplama Yöntemi}

$\mathrm{Bu}$ araştırmanın temel amacı, pandemi döneminde işletmelerin çevre koşullarına uyum sağlamak adına ürünlerinde hangi inovasyonları gerçekleştirdikleri ve bunların yönetim ve pazarlama bilimlerine etkilerinin neler olduğunun belirlenmesidir. $\mathrm{Bu}$ bağlamda araştırma; işletme, ürün, stratejik ve yönetim inovasyonlarından oluşan inovasyon kümesi bağlamında değerlendirilmiştir. Pandemi döneminde yaşanan inovasyonlarla ilgili literatürde sınırlı sayıda araştırma bulunmaktadır. Bu nedenle araştırmanın literatüre katkı sağlaması öngörülmektedir.

Araştırmada verilerin elde edilebilmesi için nitel veri toplama yöntemlerinden mülakat metodu (görüşme) tercih edilmiştir. Bu yöntem biçimsel, yarı biçimsel ve biçimsel olmayan şeklinde üç gruba ayrılmaktadır (Yıldırım, 2017, s. 124). Görüşme esnasında kullanılacak olan mülakat soruları daha önce literatürde yapılmış araştırmalardan faydalanılarak hazırlanmıştır. Ancak görüşme sürecinde soruların daha 
iyi anlaşılabilmesi açısından esneklik sağlanmış ve katılımcılara ek sorularda sorulmuştur. Bu nedenle bu araşırmada yarı biçimsel mülakat tekniği kullanılmıstır. Bu şekilde işletmelerin pandemi döneminde ürünlerinde ne gibi inovasyonlar yapmak zorunda kaldıkları ve bu inovasyonların işletme üzerindeki olumlu veya olumsuz etkileri incelenmiştir.

\subsection{Araştırmanın Evreni ve Örneklemi}

Araştırma Konya İlinde faaliyet gösteren ilk, orta ve lise eğitiminden biri, birkaçı veya hepsini veren sekiz özel eğitim kurumu aracılığyla gerçekleştirilmiştir. Özel eğitim kurumlarının örneklem olarak belirlenmesindeki en önemli etken, pandemi sürecinde sunulan üründe inovasyonun etkisinin en fazla görüldüğü sektörlerden birisinin eğitim sektörü olmasıdır. Ayrıca özel okulların yaşadıkları rekabet düşünüldüğünde, bu değişimlere anında uyum sağlayabilmesi varlıklarını devam ettirebilmesi açısından önemli bir husustur. Bu nedenle bu süreçte özel eğitim kurumlarının inovasyon çalışmalarını çok hızlı bir şekilde gerçekleştireceği ve çalışma için iyi bir veri kaynağı olacağı öngörülmüştür. Araştırma kapsamında özel eğitim kurumlarının yöneticileri ile görüşülmüştür. Son görüşmeden sonra verilen cevapların farklılaşmadığı ve diğer mülakatlarla benzerlik oranının arttığı gözlemlenmiş ve kattlımcı sayısının sekiz olmasının uygun olacağı düşünülmüştür. Görüssme esnasında elde edilen bilgilerin işletme gizliliğini ihlal edebileceği öngörüsüyle katılımcı ve kurum adları paylaşılmamıştır. Katılımcılarla ilgili bilgiler Tablo 4'te görüssme takvimi sırasına göre gösterilmektedir.

Tablo 4. Katulımcilarla İlgili Bilgiler

\begin{tabular}{|c|c|c|c|}
\hline Katılımcılar & Cinsiyeti & $\begin{array}{c}\text { İş Deneyimi } \\
\text { Süresi (Y1) }\end{array}$ & İşletmedeki Görevi \\
\hline Katılımc1 1 & Erkek & 18 & Okul Müdür Yardımcıs1 \\
\hline Katılımc1 2 & Erkek & 16 & Yönetim Kurulu Üyesi \\
\hline Katılımc1 3 & Erkek & 13 & Genel Müdür \\
\hline Katılımc1 4 & Erkek & 30 & Okul Müdürü \\
\hline Katılımc1 5 & Erkek & 25 & Okul Müdürü \\
\hline Katılımc1 6 & Erkek & 18 & Okul Müdürü \\
\hline Katılımc1 7 & Erkek & 23 & Okul Müdürü \\
\hline Katılımc1 8 & Erkek & 30 & Genel Müdür \\
\hline
\end{tabular}

\subsection{Araştırmada Tercih Edilen Veri Toplama Süresi ve Sınırlılığ1}

Mülakat sürecinde katıllımcılara çalışmanın esasına yönelik yarı biçimsel tekniğinin gerektiği biçimde sorular hazırlanmıştır. Ardından katılımcılardan uygun gün ve saatte randevu alınarak bir görüşme takvimi oluşturulmuştur. Görüşmeler bu takvime göre pandemi kurallanna riayet ederek gerçekleştirilmiştir. Yapılan her bir görüşme için ayrıntılı notlar tutulmuş ve tüm görüşmelerin ses kaydı alınmıştır. Her bir görüşme 40 ile 60 dakika arasında gerçekleşmiştir. Araştırmada kullanılan ana sorular şöyledir:

1) Kisaca kendinizden bahseder misiniz?

2) Bu kurumda ne kadar süredir çalısıyorsunuz? Kurumdaki sorumluluklarınız nelerdir?

3) Covid-19 pandemi sürecinde uzaktan eğitimle ilgili kurumunuzda yapılan işletme inovasyon çalışmaları hakkında bilgi verir misiniz?

4) Covid-19 pandemi sürecinde eğitim hizmetleri ile ilgili yapmıs olduğunuz ürün inovasyonlanı nelerdir?

5) Kurumunuzda pandemi döneminde yaptı̆̆ınız stratejik inovasyon çalışmaları var mıdır? Varsa nelerdir?

6) Yönetim olarak Covid-19 pandemi sürecinde işletmenizin ve çalışanlannızın değişen şartlara oryantasyonunu sağlamak için ne tür yönetim inovasyon çalışmaları gerçekleştirdiniz/gerçekleştirmektesiniz?

Mülakat esnasında soruların daha rahat cevaplanabilmesi için kattlımcılara inovasyon kümesi hakkında gerekli açıklamalar yapılmıştır. Araştırma sonucunda elde edilen ses kayıtları deşifre edilmiş ve tutulan notlar eşliğinde tüm katılimcılara ait mülakat verileri elde edilmiştir.

Pandemi döneminde özel eğitim kurumlanının verdiği hizmetlerde yaşanan belirsizlikler, sürecin çok yeni olması ve süreci etkileyen değişkenlerin hala netleşememesi, sosyal mesafe kuralı, yüz yüze 
temaslardan kaçınma, sokağa çıkma ve şehirlerarası yolculuk ve benzeri kısıtllı1klar, eğitim kurumları ile görüşmelerde bir sınıllı1ı oluşturmuştur. Ayrıca zaman ve ekonomik kısıtll11klarda araştırmaya ait diğer sinirliliklardir.

\subsection{Verilerin Analizi}

Araştırmada nitel analiz yöntemlerinden "içerik analizi” kullanılmıştır. Bu nedenle öncelikle elde edilen veriler araştırma amacı esasında içerik analizine uygun olacak şekilde tasnif edilmiştir. Ardından bu veriler, nitel araştırma yöntemlerinde sıklıkla kullanılan MAXQDA 18 programı aracılı̆̆ıyla kodlanmış ve verilerin analizi gerçekleştirilmiştir.

\subsection{Nitel Araştırmanın Güvenilirliği}

Nitel araştırmalarda sonuçların güvenilirliğinin sağlanması için, analizi yapan farklı kişilerin benzer sonuçları bulması esastır. Bu durum kodlama mutabakatı ile sağlanmaktadır. Bu süreçte iki farklı araştırmacı elde edilen verileri kodlar ve kodlama sonucunda araştırmacıların analizlerinin benzerlik oranı kontrol edilmektedir. Benzerlik oranının kabul edilebilir bir uyumlulukta olması beklenmektedir. Bu araştırmada kodlama mutabakatı benzerlik oranı \%83 çıkmış ve bu oranın kabul edilebilir olduğu belirlenmiştir.

\subsection{Araştırmanın Bulguları}

Elde edilen veriler Kod İlişkileri Matrisi ve Kod-Alt Kod Araştırma Modeli aracıllğıyla analiz edilerek, özel eğitim kurumlarında pandemi sürecinde inovasyon kümesi kapsamında yapılan inovasyon çalışmalarının neler olduğuna ve bunların etkilerine ulaşılmaya çalışılmışır. Araşıırma sürecinde elde edilen veriler inovasyon kümesi (işletme, ürün, stratejik ve yönetim) kapsaminda değerlendirilmiştir. Ancak özel eğitim kurumlarında yapılan inovasyonların, inovasyon kümesi ile ilişskilerinin daha açı bir şekilde belirlenebilmesi için ek olarak alt kodlama başlıkları (Sınıf Özellikler, Sınıf İçi Materyaller, Dijital Eğitim Araçları, Derslerin İşlenme Süreci, Sınavlar, Ödevler, Sosyal Aktivite Alanları Ve Donanımlar, Planlama, İnsan Kaynakları Seçimi, Oryantasyon, Karar Alma Süreci, Rekabet Üstünlüğü, Örgün Ve Uzaktan Eğitim Modellerinin Karşılaştırılması, Verimlilik Ve Sektörün Geleceğine Yönelik Öngörü) oluşturulmuştur. Her bir alt kod, inovasyon kümesi unsurlan ile ilişkilendirilerek inovasyon kümesi çerçevesinde yapılan inovasyon çalışmalan değerlendirilmiştir. Ancak analiz sonucunda elde edilen verilerin her birine çok kapsamlı ve uzun olması nedeniyle araştırmada yer verilememiştir.

Şekil 2'de Kod İlişkileri Matrisi gösterilmiştir.

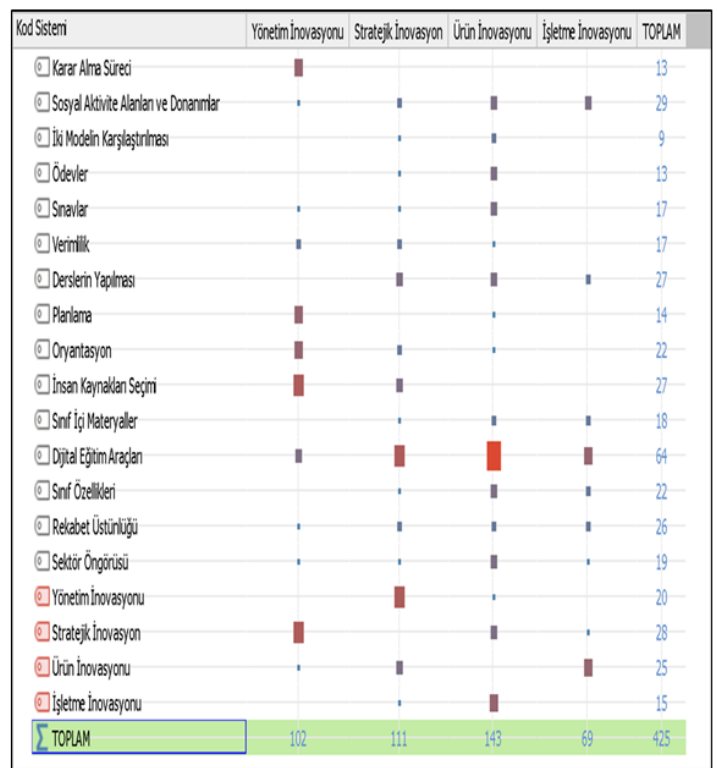

Şekil 2. İnovasyon Kümesi Kod İlişkileri Matrisi 
Şekil 2'de tüm kodların birbirleriyle olan ilişkisi gösterilmektedir. Bu bağlamda yönetim inovasyonunun, en çok "karar alma süreci, planlama, oryantasyon, insan kaynaklanı seçimi, dijital eğitim araçlan ve stratejik inovasyon" ile ilişkisi vardır. Stratejik inovasyonun en çok ilişki kurduğu kodlar "dijital eğitim araçları, yönetim inovasyonu, insan kaynakları seçimi, derslerin yapılmasıdır". Ürün inovasyonunun "dijital eğitim araçları, işletme inovasyonu, sosyal aktivite alanları ve donanımlar, ödevler, sınavlar, derslerin yapılması, sınıf özellikleri” kodlan ile daha çok ilişki kurduğu belirlenmiştir. İşletme inovasyonu ise en çok "sosyal aktivite alanları ve donanımlar, dijital eğitim araçlanı, ürün inovasyonu, sınıf içi materyaller, sınıf özellikleri, rekabet üstünlüğü ve derslerin yapılması” kodları ile ilişki içerisindedir.

Şekil 3’te İnovasyon Kümesi Kod-Alt Kod Model analizi gösterilmiştir.

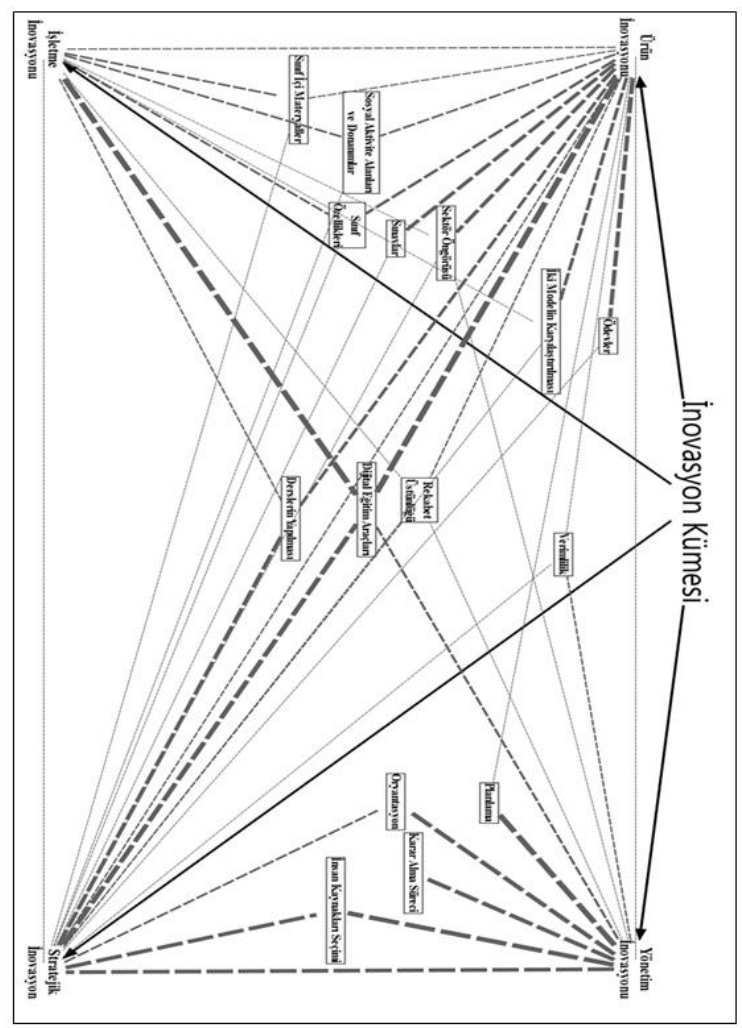

Şekil 3. İnovasyon Kümesi Kod-Alt Kod Modeli

Şekil 3’te görüldüğü üzere, analiz sürecinde, inovasyon kümesi unsurlarından yönetim ile stratejik inovasyonun ve ürün ile işletme inovasyonunun yakın ilişki içerisinde olduğu ve örneklerde benzerlikler gösterdiği tespit edilmiştir. Bu nedenle araştırmanın analizi ve yorumlamalanında, yönetim ile stratejik inovasyonun tek başlik altında yönetim ve organizasyon bilimi kapsamında, ürün ile işletme inovasyonunun ise yine tek başlık altında üretim yönetimi ve pazarlama bilimi kapsamında değerlendirilmesi uygun görülmüştür. Bu kodlamalara ilişkin katılımcıların verdiği cevaplar aşağıdaki gibidir.

\section{Yönetim ve stratejik inovasyon:}

Katılımcıların yönetim ve stratejik inovasyonla ilgili verdiği cevaplar, bu kodlarla ilişkili alt kodlar (insan kaynakları seçimi, oryantasyon, planlama, karar alma süreci, dijital eğitim araçları, derslerin yapılması) kapsamında aktarılmıştır.

“...Pandemi döneminde, insan kaynakları seçimi konusunda çok değişiklik yaşanacağını tahmin etmiyorum. Sadece kişinin kendi branş yeterliliğinin yanı sıra, teknolojik donanıma sahip olmasının da önemli olacağı kanaatindeyim. Yani teknolojik alet, teçhizat ve yazılımlan, kendi branşına entegre edebilen ve sorunsuz bir şekilde kullanabilen kişilerin işe alım sürecinde daha ön plana çıkabileceğini düşünüyorum..." 
“...Toparlamak gerekirse, eğitim sektöründe, insan kaynakları açısından aranan ve fark yaratan en önemli unsurlardan birisi deneyimdi. Ancak bu süreçte, çok daha az deneyime sahip olmasına rağmen teknolojik sürece çok daha kolay uyum sağlayabilen ve branşına entegre edebilen genç öğretmen arkadaşlarımız fark yaratıyorlar..."

“...Uzaktan eğitim sisteminin bize sağladı̆̆1 en önemli fayda personelimizin çift taraflı kontrolüdür. Daha önce bir öğretmen derse girdiğinde öğrencileri ile baş başa kaliyordu ve öğretmenin değerlendirilmesi öğrencilerin üzerinde bıraktığı etki ve öğrencilerin yorumlarıyla ölçülüyordu. Şu anda ise ögrretmen derse girdiğinde hem veli hem de idareciler olarak bizler öğretmen performansını görebiliyor ve değerlendirmelerimizi kendi yorumlarımıza göre yapabiliyoruz. Bu bağlamda insan kaynaklarının denetimi ve performans değerlendirmesi konusunda çok farklı bir kaynak elde etmiş olduk..."

“...Öğretmenlerin kalitesinin belirlenmesi hususunda daha önce öğrenci yorumları etkili oluyordu. Şimdi tüm öğretmenlerimiz hem veliler hem de idareciler tarafindan rahatlıkla izlenebiliyor. Bu durum ögretmen kalitesinin belirlenmesinde yeni bir değerlendirme süreci oluşturdu...”

“...Kurum olarak süreçlerimize akıllı tahtalar ve interaktif paneller gibi dijital eğitim araçlarını daha önceki yıllar eğitim sistemimize entegre ettiğimiz için öğretmenlerimizin bu unsurlan kullanma yetenekleri, işe alım sürecimizde zaten aradığımız bir yetkinlikti. Ayrıca mevcut öğretmenlerimizi de bu konuda bir teste tabi tuttuk ve eksiği olan öğretmenlerimize kurum içi eğitim ve oryantasyon hizmetleri ile bu sürece hazırladık. Her yıl insan kaynaklarımızdan gelen taleplere göre düzenli olarak bu eğitimlerimizi tekrarliyoruz."

“...Tabi her ne kadar sürekli kurum içi eğitim versek de dijital dünya sürekli kendini geliştiriyor ve bu sebeple kullanılan sistemlerin güncellenmesi gerekiyor. Zaten değişim kaçınılmaz bir unsur. Değişim esnasında işin doğası gereği öğretmenlerimizde illaki sorgulama boyutunda bir direnç görüyoruz. Ancak eğitimler esnasında sürecin bize katacaklarını izah ettiğimizde ve sunduğumuz eğitim ve oryantasyon hizmetleri aracılığılla, kısa sürede adapte oluyorlar ve kendimizi güncelleyerek yolumuza devam diyoruz..."

“...Örgün eğitimde planlamaya etki edebilecek tüm faktörleri biliyor ve kontrolünü sağlayabiliyorduk. $\mathrm{Bu}$ nedenle planlama ile ilgili belirli şablonlarımız, hazırlıklarımız oluşabilecek tüm problemlere karşı anında geliştirebileceğimiz çözüm önerilerimiz vardı. Bugün ki pandemi sürecinde ise planlama konusunda bize problem yaratan en önemli unsurlardan birisi belirsizliktir. Bakanlığın belirlediği hangi öğrencilerin ne şekilde örgün veya online derse devam edeceğine dair bir takvim var. Bu takvimde hakl1 olarak hastalığın seyrine göre sürekli revize ediliyor. Pandemi döneminin ne şekilde bir süreç izleyeceğini de net bir şekilde kimse öngöremediği için planlama süreçlerimizde değişiklikler yaşanmaya devam edecek gibi görünüyor..."

“...Pandemi döneminde, planlama konusundaki iş yükü önceki döneme göre çok fazla arttı ve değişiklikler yaşandı. Daha fazla unsuru dikkate alarak çok detaylı bir planlama yapmanız gerekiyor. Çünkü eğitimi veren öğretmen, eğitimi alan öğrenci, aracılık edecek altyap1 düşünüldüğünde, kurum olarak müdahale edemeyeceğiniz faktörler ortaya çıkıyor. Örneğin öğrencinin uzaktan eğitime erişimi konusundaki kaynakları (bilgisayar veya internet altyap1sı) bizim doğrudan müdahale edemediğimiz ancak eğitim kalitemizi doğrudan etkileyen unsurlar. Bu sebeple planlama sürecinde tüm bu unsurlara dikkat etmek gerekiyor. ..."

“...Kurumumuz ilgili kararları idareciler değil, ilgili kurullar alır. Pandemi döneminde, daha önceki dönemlere nazaran sıklıkla kararı alacağımız konu hakkında bizlerden daha ehil olacağını düşündüğümüz için dijital eğitim araçları ve bilgi işlem konusunda uzman olan kişilerden danışmanlık aldık. Ayrıca diğer paydaşlarımız olan öğretmenlerimizle ve velilerimizle bu süreçte aktif şekilde görüştük ve onların da görüşlerini kurullara aktararak, kurulların en uygun kararları almasını sağladık..."

“...Pandemi döneminde planlama ve karar alma süreçlerine otomasyon ve dijital eğitim araçları hakkında daha fazla bilgisi olan kişileri sıklıkla dâhil ediyoruz..."

“...Artık bu süreçlerde karar alırken bilgi işlemci arkadaşlara danışıyoruz. Pandemi sürecinde, yapmak istediklerimizi yazılım ve dijital eğitim araçlarını kullanmayı bilen çalışanlarımıza danışıyor, yapılabilirliğinin onayını aldıktan sonra kararlarımızı alıyoruz..."

“...Bu nesil dijital bir nesildir. Dijital alet ve teçhizatlarla o kadar iç içeler ki, klasik eğitim araçlarını tek başına kullanarak onların dikkatini çekmek giderek zorlaşıyor. Çünkü öğrenme ve algılama kanalları değişti. 
Dijital eğitim araçları onların algılarını, dikkatlerini ve öğrenme isteklerini canlı tutuyor. Bu nedenle öğrencilerin ne istediğini ve neye ihtiyacı olduğunu belirlemek gerçekten çok önemli...”

"...kurum içinde uzaktan eğitim modelinde kullanılan ders notları, ödev formları gibi tüm belgeler tek tiptir ve kuruma ait belgelerdir. Hatta öğretmenlerimizin kullandığı bilgisayarların masaüstü resimleri bile tek tip hale getirildi. Durum ile ilgili teknik desteği de çok yoğun şekilde sağladık. Kurumumuzun ve öğretmenlerimizin işindeki bu ciddi tavrı, öğrencilerimize de geçti ve onlarda uzaktan eğitim derslerini aynı ciddiyetle takip ettiler ve etmeye de devam ediyorlar. Kanaatimce sürecin bu şekilde yönetilmesi stratejik açısından en optimum çözümdür..."

\section{Ürün ve işletme inovasyonu:}

Katılımcıların ürün ve işletme inovasyonu ile ilgili verdiği cevaplar, bu kodlarla ilişkili alt kodlar (dijital eğitim araçları, derslerin yapılması, sınıf özellikleri, sınıf içi materyaller, sosyal aktivite alanlanı ve donanımlar, rekabet üstünlüğü ödevler, sınavlar) kapsamında aktarılmıştır.

“...Uzaktan eğitimle ilgili tüm altyapıyı 1 hafta içinde tamamladık ve tüm faaliyetlerimizi en yaygın kullanılan platformlarla entegre hale getirdik. Okul içindeki tüm süreçlerimizi, öğrencilerin en pratik şekilde kullanacağı hale getirdik. Bu süreçte en dikkat ettiğimiz husus ise her bir sınıfi aynı örgün eğitimdeymiş gibi ayrı ayrı ele almamızdır. Yani ders zili de çalıyor, yoklamada alınıyor, hatta çocuk derse girmemişse rehberlik öğretmenimiz veliyi arayıp, öğrencinin neden derse girmediğini sorguluyor. Tabi bu süreçte ilgili online platformlara, kurumumuzun süreçleriyle ilgili bilgi vererek taleplerimizi ilettik. Ardından bize özgü çözüm önerileri geliştirdiler ve çok daha işlevsel bir platform oluşturuldu. Platformlar haricinde, internet altyapımızı geliştirdik. Şu anda kurumumuzda, 100'e yakın öğretmenimiz aynı anda online ders yapabiliyor..."

“...Örgün öğretimde dijital eğitim araçları, uygulama sınıflanı, öğrencilerin sosyal aktiviteleri yapabilmesi için ayrılmış alanlar, eğitim seviyesine göre ayrılmış kullanım ve oyun alanları, sınıf içi oturma düzeni, kullanılan tahtanın boyutu, öğrencinin oturduğu sıra, tahtayı görme açısı gibi birçok faktör özel okullar için fark yaratan ve dikkat edilen unsurlardır. Pandemi döneminde ise öncelikler haliyle değişti. Artık kullanılan yazılımlar, öğrenci ve velilerinizle online iletişim sürecinizin sıklı̆g ile şekilleri çok daha önemli hale geldi..."

“...Örgün eğitim döneminde sınıflarımız 24 kişiliktir. Görsel olarak ders işleme alt yapımızda mevcuttur. Bu yeni dönemle birlikte bizde online ders işleyebileceğimiz, piyasada mevcut olan bir iki sistemle anlaşma sağladık. Daha sonra öğrencilerimizi ve öğretmelerimizi bu sisteme kaydettik. Şimdi bu platformlar aracilığıyla canlı derslerimiz gerçekleştiriliyor. Özetle, örgün eğitimde sınıf ambiyansı, kullanılan materyaller, sıra düzeni, sınıf büyüklüğü vb. somut unsurlara dikkat ederken, şu anda kullanılan yazılım, yazılımın güvenliği, erişim hızı, sistemin donanımları ve bir problemle karşılaştığınızda servis desteğinin hızı ve problem çözme yeteneği ön plana çıktı..."

“...Özel okullar olarak, binalar, peyzaj, derslikler, 1sınma, aydınlatma vb. çok fazla giderimiz var. Uzaktan eğitim ana eğitim modeli olursa kusursuz online bir platforma sahip olmak çoğu maliyetlerin düşmesine yol açacaktır. Ancak maliyetlerin düşmesi, muhtemelen ürününüzün yani eğitimin kalitesinin de düşmesini sağlayacaktır. Bu kesinlikle tercih edeceğimiz bir anlayış değil..."

“...Özel okullar için örgün eğitimde fiziki unsurlar açısından sahip olmanız gereken belirli standartlar vardır. İçinde bulunduğumuz pandemi dönemi, bu standartların biraz daha yükselmesine sebep oldu. Örneğin, örgün öğretimde her bir sınıfta 24 öğrencimiz eğitim görürken, bu sayılda yeni düzenlemeler yapmak zorunda kaldık. Sıralarımız iki kişilikti, sosyal mesafe gereğince yine her bir öğrencimizi tek bir sırada oturtacak şekilde revizeler gerçekleştirdik..."

“...Kurumumuz online eğitim platformuna daha önceki ylllarda yani içinde bulunduğumuz pandemi dönemi yaşanmadan yatırım yapmıştı. Bunun için büyük bir veri tabanı oluşturduk. Kurum olarak bünyemizde sadece bu işle ilgilenmesi için bir yazılımcı çalışırıyoruz. Tabi sadece alt yapı ile iş bitmiyor. Ayrıca bunun için özel bir stüdyo kurduk. Öğretmenlerimiz teker teker kendi dersleri ile ilgili profesyonel bir şekilde ders videoları çektiler. Montajı vb. işler ardından kurduğumuz sisteme bu videolarımız aktardik..." 
“...Kurumumuzun arama notları vardır. Rehber ve branş öğretmenlerimizin öğrenci ve veliler ile yaptıkları görüşmeler, durum ile ilgili belirlenen eksiklikler, talepler ve öğrenci hakkındaki görüşler not alınır ve elden sınıf öğretmenlerine teslim edilir. Şimdi bu süreçlerin hepsi dijitalleşti ve bilgi akışı sistem üzerinden gerçekleştirilmeye başlandı. Şu süreçte kurumla ilgili veri iletiminin online platformlar üzerinden yapılması gerekliliği ortaya çıtı. Çünkü çoğu işte inanılmaz bir zaman ve emek tasarrufu sağladık. Mesela, randevulu veli toplantısı yaptık. Bir başka örnek, genel sınavların soru çözümlerini tüm öğretmenlerimiz tahta üzerinde çözüyordu. Şimdi bu platformlar üzerinden soru çözümlerini videosunu çekiyor ve sınavın hemen ardından öğrencilerimizle paylaşıyoruz. Bu durum öğrenci ve öğretmenin birlikte geçirdiği zamanın kalitesini de olumlu yönde etkiliyor..."

“...Uzaktan eğitim uygulamalarına yatırım yapmak ve gerekli tüm altyapıyı sağlamak rekabet edebilmek için gerçekten çok önemli. Çünkü bu ana ürününüz olan eğitimi aktarmanız için ana sağlayıc1 konumunda..."

“...Kurum olarak öğretim kadromuzun uzun yıllar aynı kalması bize rakiplerimize nazaran bir üstünlük sağlamaktadır. Tabi günümüzde rekabet edebilmek için sadece eğitim kalitenizin iyi olması yeterli olmuyor. Artık velilerimiz eğitim kalitesinin yanı sıra çocukların sosyalleşebileceği farklı aktiviteler ve fiziki donanımlar istiyor. Kendimizi bu konuda geliştirmek için planlamalarımız yaptık ve gerekli yatırımları kısa süre içerisinde tamamlayacağız..."

“...Örgün eğitimde, ders işleme ve ödevler konusunda kontrolün tamamen öğretmenin elinde olduğu bir süreç vardı. Çünkü yüz yüze eğitimde öğrencinin hal ve hareketlerinden, davranışlarından hatta jest ve mimiklerinden ne hissettiğini, neler yapıp yapmadığını çok iyi analiz edebiliyorduk ve süreçte düzeltici bir müdahale gerekliyse anında bu müdahaleyi gerçekleştirebiliyorduk. Bu sebeple kontrol bizdeydi. Ancak bugün ki uzaktan eğitim modelinde, süreci bu kadar rahat kontrol edemiyoruz..."

“...Ödev, öğrencilerimize verdiğimiz kazanımların elde edilip edilmediğini kontrol ettiğimiz bir unsurdur. Öğrenci ödevini evde yapar ve okula geldiğinde öğretmeni tarafindan kontrol edilir. Şimdi öğrencilerimiz okula gelemiyorlar. Bu kazanımın oturup oturmadığını mecburen kontrol etmemiz lazım. Şu anda dijital ortamda bu süreç devam ettirilmeye çalışllyor. Ancak öğretmenlerimizin ödev kontrol sürecine müdahale şansı önceki kadar değil...”

“...Örgün eğitimde öğrenciler ödevlerini yapıp öğretmenin kontrolüne sunuyorlardı. Şimdi öğretmenlerimiz derslerini işliyor, akşam evine gittiğinde günlük verdiği ödevlerin hepsini teker teker kontrol edip, öğrencilerine görüş bildiriyorlar. Bu konuda öğretmenlerimize düşen yük çok arttı..."

"...S Snavlarda interaktif şekilde devam ediyor. Ancak tabi bu sınavlarda herkesin bildiği gibi ölçme değerlendirmenin güvenliği çok önemli bir konudur. Şimdi yapılan interaktif sınavlarda, kurum olarak bu güvenliği tek başımıza sağlamamız mümkün değil. Kanaatimce, sınavı uzaktan yapmak işin doğasına ve tabiatına aykırı bir durumdur. Dolayısıyla sınavlar konusunda çok verimli bir süreç işliyor demek çok doğru değil..."

Araştırma sürecinde, örgün ve uzaktan eğitim sisteminin kıyaslanması, verimlilik ve sektörün geleceğine yönelik farklı bulgularda elde edilmiştir. Tüm katlımcılar uzaktan eğitim modelinin verimlilik açısından örgün eğitim modeli yerine geçemeyeceği konusunda hemfikirdir. Bu değerlendirmede, özellikle öğrencilerle kurulacak duygusal bağın, öğrencinin yaşı ve eğitim seviyesinin önemine değinmişlerdir. Ancak uzaktan eğitim modelinin getirdiği avantajlarının da göz ardı edilemeyeceğini de ifade etmişlerdir. $\mathrm{Bu}$ bağlamda sektörün geleceği açısından uzaktan eğitim modelinin ana eğitim modeli olan örgün eğitimi destekleyecek bir model olacağı inancı yaygındır. Ayrıca uzaktan eğitim modeli vasıtasıyla, kurum içinde çoğu faaliyetlerin zaman ve emek kaybını önleyeceği görüşü hâkimdir. Bu bulgulara yönelik katılımcıların görüşleri aşağıdaki şöyledir.

“...Uzaktan eğitimde yüz yüze eğitime nazaran çok iyi verimlilik aldığımızı düşünmüyorum. Ancak şöyle de bir durum var, uzaktan eğitim döneminde öğretmenler ile öğrencilerin geçirdiği etkin süre çok daha fazla. Bu her ne kadar verimliği olumlu etki eden bir unsur gibi düşünülse de aslında eğitimde karşılıklı etkileşimin olması verimlilik açısından çok daha önemli bir unsur..."

"...Genel olarak yüz yüze eğitimin uzaktan eğitim modeline göre çok daha verimli olduğu kanaatindeyim..." 
“...Yüz yüze eğitimin yerini uzaktan eğitim kesinlikle tutmaz. Tabi bu süreçte esasen öğrencileri bulundukları eğitim düzeyine göre sınıflandırmak lazım. Örneğin lise öğrencileri ilk ve ortaokul öğrencilerine göre daha olgunlaşmış, bireysel karar alabilen, sosyalleşmesini ve duygusal gelişimini tamamlamış bir seviyede. Bu sebeple de teknik olarak bu sürece daha yatkınlar. Ortaokul öğrencilerinde işin içerisine duygular dâhil oluyor. Ayrıca ailelerde bu sürecin içinde daha fazla rol oynuyorlar. Hele ki ilkokulda iş neredeyse tamamen duygularla yürüyor. Bu nedenle özellikle ilk ve ortaokul seviyesinde, uzaktan eğitim kesinlikle ana eğitim modeli olamaz...."

“...Gelecekte uzaktan eğitim, yüz yüze eğitim modelini destekleyen yardımcı bir alternatif olabilir..."

“...Benim öngörüm uzaktan eğitim modeli, ana eğitim modelin destekleyecek ve yan hizmetleri sağlayacak şekilde eğitim hayatının içinde kendine sürekli yer bulacaktır...”

“...Tüm samimiyetimle inanıyorum ki, pandemi dönemi sona erdiğinde, bu sistemleri eğitim modeline entegre etmeyen veya edemeyen özel okulların piyasada rekabet edebilme şansı kalmayacak. Çünkü bu online platformların süreçleri ne kadar hızlandırdığ1 ve hem kurum açısından hem de öğrenciler açısından verimliliği artırdığ1 görüldü. Bu nedenle kurum olarak pandemi dönemi bitse de online yapilabileceğine inandığımız dersleri, ödevleri, deneme ve tarama sınavlarını ve bazı kulüp çalışmalarını bu platformlar aracılığıla yapacağı..."

\section{Sonuç ve Değerlendirme}

Ticari hayatlarını kıyasıya bir rekabet içerisinde sürdüren tüm işletmeler, değişen çevre koşullarına anında uyum sağlamak ve gerekli gördügü inovasyonları yapmak zorundadır. Isşletmenin varlığını sürdürmek açısından elzem olan bu durum, çoğu zaman işletmenin planlaması ve kontrolü dahilindedir. Ancak günümüzde yaşanan Covid-19 pandemi dönemi gibi olağanüstü durumlarda, inovasyon yapmak işletmenin planlayacağı, kontrol edeceği ve nitekim tercih edeceği bir unsur olmaktan ziyade zaruri bir hal alabilmektedir. Bu araştırmada işletmelerin pandemi süreci kapsamında inovasyon kümesi (işletme, ürün, stratejik ve yönetim) kapsamında ne gibi çalışmalar yaptığı ve bunların yönetim ve pazarlama açısından etkilerinin neler olduğu incelenmiştir. Bu bağlamda Konya ilinde faaliyet gösteren özel eğitim kurumları örneklem olarak tercih edilmiş ve yarı biçimsel mülakat tekniği ile veriler elde edilmiştir.

Araştırma sonucunda, Covid-19 pandemi dönemi sürecinde işletmelerin inovasyon kümesi kapsamında yönetim ve pazarlamaya yönelik mevcut ve gelecek projeksiyonları açısından çeşitli inovasyonlar gerçekleştirdikleri tespit edilmiştir.

Yönetim açısından inovasyonlar incelendiğinde, özel eğitim kurumlarının insan kaynaklarının seçimi ile performans değerlendirmesi, oryantasyon, planlama ve karar alma süreçlerinde değişikliğe gidildiği görülmüş ve tüm bu süreçlerde teknolojik değişimin etkisi hissedilmiştir. Örneğin insan kaynaklan seçiminde dijital eğitim araçlannı kullanma yeteneği tercih edilen bir kriter haline gelmiştir. Ayrıca tüm çalışanlara bu konuda oryantasyon verilmiş ve istisnasız herkesten başarılı bir şekilde dijital eğitim araçlarını kullanması beklenmiştir. İnsan kaynakları performans ölçümü ve değerlendirme sürecinde ise kökten bir değişiklik yaşanmıştır. Daha önce bir öğretmenin sınıf içi performansı ve değerlendirmesi, öğrencilerden elde edilen veriler aracılığıyla yapılırken, pandemi sürecinde öğretmenin sınıf içi performansı tüm paydaşlar tarafından izlenebilmiş, bu bağlamda performans ve değerlendirme kaynakları değişmiştir. Karar alma süreçlerinde özel eğitim kurumlarında kurulların etkinliği göze çarpmaktadır. Karar alma sürecinde çok fazla değişiklik yaşanmasa da bu dönemde kurulların sıklıkla bilgi işlem uzmanları danışmanlığına ihtiyaç duyduğu ve örgüt etkinliği açısından katılımcı yönetim anlayışını benimsedikleri belirlenmiştir. Planlama açısından ise çoğu katılımcı süreçte çok fazla belirsizlik yaşandığını ifade etmiş ve özellikle planlamaya etki eden paydaş sayısının artması, bu paydaşların eğitimin gerçekleştirilebilmesi için sahip olduğu veya olmadı̆̆1 unsurlar gibi nedenlerle sürecin çok zorlaştığını ifade etmiştir.

Yönetimde "en iyi yöntemin olmadığı" ve "en iyinin” içinde bulunulan duruma göre değiştiği fikrini destekleyen ve organizasyon yapısının oluşturulmasında, çevre faktörüne vurgu yapan "Durumsallık Yaklaşımı" (Lorsh, 1977, s. 2-3), günümüz pandemi dönemi içerisinde işletmelerin bulunduğu duruma esnek bir şekilde nasıl adapte olmaları gerektiğini ve organizasyon yapılarını nasıl şekillendireceklerini ifade etmiştir. Bu bağlamda eğitimin hibrit veya uzaktan yapıldığı günümüz şartlarında, işletmelerin bu sürece ayak uydurabilmeleri açısından içinde bulunduğu mevcut şartlara göre en iyi yapıyı bulmak ve uygulamak 
zorunda oldukları görülmektedir. Sonuç olarak, işletme yöneticilerine büyük sorumluluklar düşmektedir. Çünkü bu süreçte alınacak yanlış kararlar işletmelerin sürdürülebilirliğine büyük zararlar verebilecektir.

Pazarlama açısından inovasyonlar incelendiğinde ise dijital eğitim araçlarının dersler, ödevler ve sınavlarla ilgili tüm süreçleri, sınıfların özelliklerini ile kullanılan materyalleri, sosyal aktivite alanları ve okulların sahip olduğu donanımlarını etkilediği sonucuna ulaşılmışır. Ayrıca işletmelerin rekabet stratejilerini uzaktan eğitim modeline göre revize ettikleri ve gelecekte bu modelden faydalanacakları tespit edilmiştir. Örneğin dijital eğitim araçlarının etkin olması ile, dersler, ödevler ve sınavlar online platformlar aracılığıyla gerçekleştirilmeye başlanmıştır. Böylelikle örgün eğitim döneminde, özel okullarnn sunduğu hizmette farklılık yaratan, sınıflar, binalar, sınıf içi materyaller, sosyal aktivite alanlar vb. gibi ayrıcalıkların günümüz pandemi döneminde etkisi kalmamış, bunun yerine kullanılan yazılımlar, yazılımların güvenilirliği ve destek hizmetleri ön plana çıkmıştır. Ayrıca işletmenin internet altyapısının, süreçlerini dijitalleştirmesinin ve yine bu yazılımlar aracıllğıyla müşteri ilişskilerinde yaşanan değişimlerin, özel eğitim kurumlarının talep edilmesinde fark yaratan unsurlar olduğu sonucuna varılmıstır.

Genel olarak ele alınacak olunursa; bir yaklaşım olarak inovasyon faaliyetlerinin öneminin s1k s1k vurgulanıyor olmasına rağmen, verimli ve etkili bir şekilde nasıl uygulamaya konulacağına dair çok daha az zaman harcandığ1 söylenebilmektedir. İnovasyon açısından, işletmeler için iki önemli konu özellikle vurgulanmalıdır. Bunlardan ilki; inovasyonu başanyla gerçekleştirebilmek için etkin bir şekilde yönetme, ikincisi ise inovasyonun doğru araçlar ve kanallar yardımıyla müşteri değeri oluşturacak biçimde pazara sunulmasıdır. Bir başka deyişle inovatif eylemlerin ekonomik ve sosyal değere dönüştürülmesi ancak etkin bir yönetim ve pazarlama stratejisi geliştirilmesi ile mümkündür. Yeni bir mal, yeni bir hizmet, ya da yeni bir iş süreci yaratmak, yönetim ve pazarlama sürecine tabi tutulmadıkça inovasyon kapsamında değerlendirilmesi tam anlamılla mümkün olamayacakttr. Bugünün hiper rekabet ortamında inovatif fikir üretimi hiç olmadığı kadar önem arz etmektedir. Bu bağlamda işletme yöneticilerine; özellikle fikirlerin somutlaştırılması aşamasında hem pazarlama hem de yönetim perspektifinden işletmeye rekabet avantajı sağlayacak biçimde fikirlerin değişimini vurgulayacak tarafları ön plana çıkarmaları önerilebilmektedir. Ayrıca yapılan bu çalışmanın, Konya ili özel eğitim kurumları örnekleminin genişletilip farklı illerde veya inovasyonun benzer şekilde etki ettiği farklı sektörlerde uygulanması suretiyle de gelecek çalışmalar için bir örnek teşkil edebileceği düşünülmektedir.

\section{Extended Abstract}

Almost everything around us is changing, and the ability of businesses to develop flexible and innovative strategies to cope with this situation is more important than ever. In the face of rapid changes, business managers have to seek a sustainable development path in order to survive in challenging market conditions, and this road passes through continuous innovation activities. The product, which is one of the most important elements of the marketing mix, is becoming more preferred only if it is adapted to changing customer demands and needs. The approach of selling products in line with consumer expectations, replacing the "I sell what I produce" perspective, which was dominant in the past, is an extremely critical perspective that marketing managers should not ignore. Marketing innovation covering marketing activities in the innovation process; It is considered as an approach that makes it possible to investigate customer demands and needs and to offer products that are compatible with their expectations. Since the customer is the focus of marketing, it becomes possible to align all products and processes with the needs of customers with marketing innovation. On the other hand, being able to realize innovations in line with customer expectations not only in terms of marketing but also in terms of management and process is a very important requirement in terms of management of business. Management innovation is a concept that has the ability to significantly differentiate the way practices are done from those of the traditional methods. In today's hyper-competitive environment, businesses that have to keep up with environmental changes are obliged to innovate in terms of both marketing and management activities in order to compete. This situation, which is essential for the survival of the business, is often within the planning and control of the business. However, in extraordinary situations such as the Covid-19 pandemic today, innovation can become an compulsory situation rather than an element that the business will plan, control, and as a matter, overcome. The Covid-19 pandemic, which 
affects the whole world, and this with the least damage possible. It is a global crisis in which it made significant efforts to exit the process. From the stand point of a marketing and management perspective, especially the activities based on innovation, it can be said that businesses provide significant competitive advantages over their competitors in this period.

The main purpose of this research is to determine which innovations businesses have made in their products in order to adapt to environmental conditions during the Covid-19 pandemic period and to reveal what their effects are on marketing and management sciences. For this purpose, research; It has been evaluated in the context of an innovation cluster consisting of business, product, strategic and management innovations. Qualitative analysis method was used in the study, and private scholls operating in Konya were chosen as a sample and one-to-one interviews were made with administrators using the semi-formal interview technique. In this way, it has been tried to learn what kind of innovations businesses have made in their products during the pandemic period and the positive or negative effects of these innovations on the business. The data obtained as a result of the interview records were coded by using the MAXQDA 18 program which is frequently used in qualitative research methods, and then were analyzed. As a result of this research, it was determined that during the Covid-19 pandemic period, enterprises carried out various innovations in terms of current and future projections for management and marketing within the scope of the innovation cluster. There is a limited number of studies in the literature on innovations experienced during the pandemic period. For this reason, it is foreseen that the research will contribute to the literature.

\section{Kaynakça}

Aksoy, H. (2017). How do innovation culture, marketing innovation and product innovation affect the market performance of small and medium-sized enterprises (SMEs)? Technology in Society, 51, 133-141.

Alegre, J., \& Chiva, R. (2008). Assessing the impact of organizational learning capability on product innovation performance: An empirical test. Technovation, 28(6), 315-326.

Aygen, Selin (2006). İ̧lletmelerde yenilik yönetimi sürecinde örgüt yapularnda ve hiæmet tasarmmlarnda yaşanan

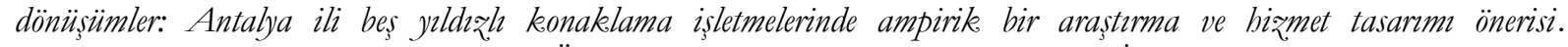
Yayımlanmamış doktora tezi, Selçuk Üniversitesi, Sosyal Bilimler Enstitüsü, İşletme Anabilim Dalı, Konya.

Biçimveren, L. (2017). Pazar odaklhke, yenilik odaklhhk, pazarlama inovasyonu ve uluslararası pazar performansi: Ballkesir ve bursa illerinde dis ticaret yapan firmalara yönelik bir uygulama. Yayımlanmamış yüksek lisans tezi, Balıkesir Üniversitesi, Sosyal Bilimler Enstitüsü, Uluslararası Ticaret ve Pazarlama Ana Bilim Dalı. Balikesir.

Biloshkurska N. V., Biloshkursky, M. V., \& Kravchenko R. O. (2017). Marketynhovyi analiz stratehichnoi konkurentospromozhnosti vyshchykh navchalnykh zakladiv rehionu [Marketing analysis of the strategic competitiveness of regional establishments of higher education]. Ekonomichni horyzonty [Economies' Horizons], 2(3), 25-30.

Birkinshaw, J. \& Mol, M. (2006). How management innovation happens. MITSloan Management Rewiev, 47(4), 81-88.

Birkinshaw, J., Bouquet, C. \& Barsoux, J. (2011). Los cinco mitos de la innovacion. Harvard Deusto Business Review, 201, 12-24.

Braslavska O. V., Biloshkurska N. V. \& Biloshkurskyi M. V. (2019). Modern Innovation in Marketing Of Educational Services. İçinde: Prognostication And Planning Of Economic Development: Microeconomic And Macroeconomic Levels. (ss.400-414). Publishing House. Baltija Publishing.

Brilman, J. (2002). Nowoczesne Koncepcje I Metody Zarzadzania. Warszawa: Polskie Wydawnictwo Ekonomiczne.

Camisón, C., \& Villar-López, A. (2011). Organizational innovation as an enabler of technological innovation capabilities and firm performance. Journal of Business Research, 67(1), 2891-2902.

Cooper, R. G. \& Kleinschmidt, E. J. (1995). Benchmarking firms' new product performance and practices. Engineering Management Review, 23(3),112-120.

Cooper, R. G. \& Kleinschmidt, E. J. (1996). Winning businessesin product development: critical success factors. research? Technology Management, 39(4), 18-29 
Cooper, R.G. \& Kleinschmidt (1987). Success factors in product innovation. Industrial Marketing Management. 16, 215-223. 44.

Cooper, R.G. (2000). Product innovation technology strategy. Research Technology Management, 44(1), 38-

Cruz-Ros, S., Garzon, D., \& Mas-Tur, A. (2017). Entrepreneurial competencies and motivations to enhance marketing innovation in Europe. Psychology \& Marketing, 34(11), 1031-1038.

Demircioğlu, M.A. (2016). Organizational Innovation. Springer International Publishing AG 2016 A. Farazmand (ed.), Global Encyclopedia of Public Administration, Public Policy, and Governance. 1-6.

Devane, S. \& Wilson, J. (2009). Business benefits of non-managed knowledge. Electronic Journal of Knowledge Management, 7(1), 31-40.

Doyle, P. \& Bridgewater, S. (1998). Innovation in Marketing. Oxford: Butterwoth-Heinemann.

Drejer, A. (2006). Strategic innovation: A new perspective on strategic management. Handbook of Business Strategy. 7(1), 143-147.

Dutta, S., Narasimhan, O., \& Rajiv, S. (1999). Success in high technology markets: Is marketing capability critical? Marketing Science, 18(4), 547-568

Fuentes-Blasco, M., Moliner-Velázquez, B., Servera-Francés, D., \& Gil-Saura, I. (2017). Role of marketing and technological innovation on store equity, satisfaction and word-of-mouth in retailing. Journal of Product \& Brand Management, 26(6), 650-666.

Gebauer, H., Worch, H., \& Truffer, B. (2012). Absorptive capacity, learning processes and combinative capabilities as determinants of strategic innovation. European Management Journal, 30(1), 57-73.

Geldes, C., Felzensztein, C., \& Palacios-Fenech, J. (2017). Technological and non-technological innovations, performance and propensity to innovate across industries: The case of an emerging economy. Industrial Marketing Management, 61, 55-66.

Govindarajan, V., \& Trimble, C. (2004). Strategic innovation and the science of learning. MIT Sloan Management Review, 45(2), 67-75.

Govindarajan, V., \& Trimble, C. (2005). Organizational DNA for strategic innovation. California Management Review, 47(3), 47-76.

Grant, M. R (2008). The Future of Management: Where is Gary Hamel Leading Us? Long Range Planning, 41(2008), 469-482.

Gupta, S., Malhotra, N. K., Czinkota, H., \& Foroudi, P. (2016). Marketing innovation: A consequence of competitiveness. Journal of Business Research, 69(12), 5671-5681.

Gümüş, S. \& Gümüş, G.H. (2015). Marketing Innovation in Business. Procedia-Social and Behavioral Sciences, 181(2015), 261-268.

Gümüşlüoğlu, L. \& İlsev, A. (2009). Transformational leadership, creativity and organizational innovation. Journal of Business Research, 62(4), 461-473.

Hamel, G. \& Bren, B. (2007). The Future of Management. Harvard Business School.

Hamel, G. (1998). The challenge today: changing the rules of the game. Business Strategy Review, 9(2), 1926.

Hancıoğlu, Y. \& Yeşilaydın, G. (2016). Stratejik yönetimde yeni bir rekabet yaklaşımı.: Stratejik inovasyon. Uluslararası Yönetim İktisat ve İsletme Dergisi, 12(29), 105-124.

Hultink, E. J., Robben, H.S.J. (1995), Measuring new product success: The difference that time perspective makes. Journal of Product Innovation Management, 12(5), 392-405.

Kafetzopoulos, D., \& Psomas, E. (2016). Organisational learning, non-technical innovation and customer satisfaction of SMEs. International Journal of Innovation Management, 20(3), 1650041.

Kalivas,Y. Gkofa, F., Rakovitis, C., Tonkov, A., Petrov, V. \& Likar, B. (2013). Basic On Innovation. İçinde Borut Likar, Peter Fatur, Urška Mrgole (Ed.), Innovation Management. (ss: 13-26). Korona plus d.o.o., Institute for Innovation and Technology, Slovenia, 1st edition, 2.

Kim, N. \& Atuahene-Gima, K. (2010). Using exploratory and exploitative market learning for new product development. Journal of Product Innovation Management, 27(4), 519-536.

Kuncoro, W., Suriani, W.O., 2018. Achieving sustainable competitive advantage through product innovation and market driving. Asia Pac. Manag. Rev. 23(3), 186-192. 
Lam A (2006). Organizational innovation. In: Fagerberg J, Mowery DC (eds) The Oxford Handbook Of Innovation. Oxford University Press, Oxford.

Lee, R., Lee, J.-H., \& Garrett, T. C. (2019). Synergy effects of innovation on firm performance. Journal of Business Research, 99, 507-515.

Lorsch, J.W. (1977). Organization design: A situational perspective. Organizational Dynamics, 6(2), 2-14.

Markiewicz, J. (2010). Instytucje otoczenia biznesu. Rola w ksztaltowaniu sektora MSP na prazyktadzie województwa zachodniopomorskiego. Szczecin: Wydawnictwo Naukowe Uniwersytetu Szczecińskiego.

Medrano, N., \& Olarte-Pascual, C. (2016). The effects of the crisis on marketing innovation: An application for Spain. Journal of Business \& Industrial Marketing, 31(3), 404-417.

Medrano, N., Canamares, C.M.; Pascual, O.C. (2020). Impact of marketing innovation. Journal of Business \& Industrial Marketing. 35(1), 1-12.

Millson, M.R. (2013), Exploring the moderating influence of product innovativeness on the organizational integration-new product market succes relationship. European Journal of Innovation Management, 16(3), 317-334.

Muigai, R.G., Gitau, S.N., (2018). Effect of innovation strategies on financial performance of the banking industry in Kenya. Eur. J. Econ. Financ. Res. 3(1), 168-186.

Nadda, V. \& Arnott, I. (2019). Marketing Innovation in Tourism. İçinde Sumesh Sing Dadwal (Ed.), Handbook of Research on Innovations in Technology and Marketing for the Connected. (ss: 401-415). IGI Global.

Naidoo, V. (2010). Firm survival through a crisis: The influence of market orientation, marketing innovation and business strategy. Industrial Marketing Management, 39(8), 1311-1320.

Negulescu, H.O. (2020). Innovation management: the source of continuous improvement of competitive advantage and organization's performance. Review of General Management, 32(2), 60-75.

Ngo, L. V., \& O'Cass, A. (2012). In search of innovation and customer-related performance superiority: The role of market orientation, marketing capability, and innovation capability interactions. Journal of Product Innovation Management, 29(5), 861-877.

O’Dwyer, M., Gilmore, A., \& Carson, D. (2009). Innovative marketing in SMEs: An empirical study. Journal of Strategic Marketing, 17(5), 383-396.

OECD/Eurostat. (2005). Oslo Manual: Guidelines for Collecting and Interpreting Innovation Data. OECD Publishing.

Palmer, D. \& Kaplan, S. (2007). A framework for strategic innovation-blending strategy and creative exploration to discover future business opportunities, Innovation Point LLC, (Online) http://www.fastbridge.net/wpcontent/uploads/resources/A\%20framework $\% 20$ for $\% 20$ strategic $\% 20$ innovation.pdf., 21.24.2017, 1-22.

Purchase, S. \& Volery, T. (2020). Marketing Innovation. A systematic review, Journal of Marketing Management, 36(9-10), 763-793. Ramirez, F. J., Parra-Requena, G., Ruiz-Ortega, M. J., \& GarciaVillaverde, P. M. (2018). From external information to marketing innovation: The mediating role of product and organizational innovation. Journal of Business \& Industrial Marketing, 33(5), 693-705.

Sánchez-Gutiérrez, J., Cabanelas, P., Lampón, J. F., \& González-Alvarado, T. E. (2019). The impact on competitiveness of customer value creation through relationship capabilities and marketing innovation. Journal of Business \& Industrial Marketing, 34(3), 618-627.

Schlegelmilch, B. B., Diamantopoulos, A., \& Kreuz, P. (2010). Strategic innovation: the construct, its drivers and its strategic outcomes. Journal of Strategic Marketing, 11(2), 117-132.

Sniukas, M. (2010). Reshaping Strategy: Exploring The Content, Process And Context Of Strategic Innovation. Saarbrücken: VDM Verlag Dr. Müller Publishing.

Soylu, A. \& Göl, Ö. M. (2010). Yönetim inovasyonu. Sosyo Ekonomi, 1(100107), 112-130.

Volberda, H.W., Van Den Bosch, F.A.J.ve Heij, C.V. (2013). Management Innovation: Management as Fertile Ground for Innovation. European Management Review, 10, 1-15.

Wang, S. (2015). What motivates marketing innovation and whether marketing innovation varies across industry sectors, Phd Thesis, University of Ottawa. 
Wang, Y. (2020). The influence of market orrentation on department store floor managers' job performance- the mediating roles of organizational innovation and perceived organizational support. The International Journal of Organizational Innovation. 13(2), 35-48.

Warren, N.L. \& Sorescu, A. (2017). When 1+1>2: How investors react to new product releases announced concurrently with other corporate news. Journal of Marketing, 81(2), 64-82.

Weerawardena, J. (2003). The role of marketing capability in innovation-based competitive strategy. Journal of Strategic Marketing, 11(1), 15-35.

Wojtkiewicz, S.M. (2017). Dimension of marketing innovations and marketing of innovation in enterprises. Marketing i Zarzadzanie. 1(47), 51-58.

Wong, S. (2013). The role of management involvement in innovation. Management Decision, 51(4), 709729.

Yıldırım, İ. E. (2017). İstatistiksel Arasstıma Yöntemleri, Arasstrma Tasarmo-Örnekleme-Veri Toplama Teknikleri, Ankara: Seçkin Yayınları.

Zhang, F., Sun, S., Liu, C. \& Chang, V. (2020). Consumer innovativeness, product innovation and smart toys. Electronic Commerce Research and Applications. 41(2020) 100974, 1-14. 